ARTIKEL UTAMA

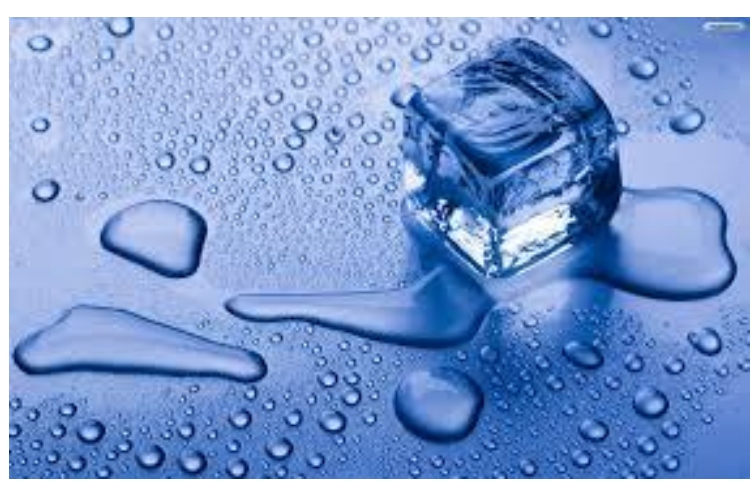




\section{Early Pentecostal Eschatology}

Gani Wiyono

\section{INTRODUCTION}

Few studies have been devoted to early Pentecostal eschatology. ${ }^{1}$ One of them, that of by Gerald T. Sheppard merits special attention. Sheppard's article attempts show that "Pentecostals were not originally dispensationalist-fundamentalist and that the efforts secondarily to embrace such views have raised new problems for the identity of Pentecostals - hermeneutically, sociologically and politically." 2 The procedure taken by Sheppard is to investigate early Pentecostal eschatology as reflected in the writings of some early Pentecostal figures. Unfortunately, he excludes some important earliest Pentecostal figures such as Charles F. Parham, William J. Seymour, and G. F. Taylor. Moreover, some important Pentecostal writers, such as Daniel W. Kerr, that merit special attention due to their distinctive eschatology, have been left out.

It is the purpose of this paper to fill "empty space" within Sheppard's article. It will investigate specifically the eschatological views of Pentecostal writers prior to 1920. The conclusion certainly affirms the Sheppard' thesis that originally the Pentecostal eschatology was not purely dispensational. Besides, it will be shown that early Pentecostal views on eschatology were not absolutely uniform. There was certainly diversity in the early Pentecostal eschatology! Before accessing and analyzing those early documents, we need to examine theological "soil" in which the Pentecostal movement took root, that is the rise of premillennialism.

I. THE THEOLOGICAL "SOIL": THE RISE OF PREMILLENNIALISM

\footnotetext{
${ }^{1}$ So far, I have found only two journal articles: Gerard T. Sheppard, "Pentecostals and the Hermeneutics of Dispensationalism: The Anatomy of an Uneasy Relationship," Pneuma (Fall 1994): 5-33; Glen W. Menzies and Gordon L. Anderson. "D.W. Kerr and Eschatological Diversity in the Assemblied of God." Paraclete (Winter 1993): 8-16.

${ }^{2}$ Sheppard, 5.
} 
It was the Great Awakening of the 1740's that brought the ascendancy of postmillennial eschatology. Jonathan Edward, the key person of the revival, believed that the revivals were just dawning in 1739 marked the beginning of a golden age prior to the physical return of Jesus Christ foretold in the Bible

Indeed, I have often said, as I say now, that I looked upon the late wonderful revivals of religion as forerunners of those glorious times so often prophesied of in the Scriptures and that this was the first dawning of that light, and beginning of that work which, in the progress and issue of it, would at last bring on the church's latter-day glory ... and Christ's Kingdom shall be everywhere established and settled in peace which will be the lengthening of the millennium. ${ }^{3}$

Jonathan Edward's vision of the literal millenium later was cultivated and refined in the holiness-revivalist tradition. Charles G. Finney, the prominent leader of the movement seems to link the theme of entire sanctification, social reformation to postmillennial expectation. ${ }^{4}$

Now the great business of the church is to reform the world - to put away every kind of sin. The church was originally organized to be a body of reformers. The very profession of Christianity implies and virtually an oath to do all that can be done for the reformation of the world. The Christian church was designed to make aggressive movement in every direction - to lift up her voice and put forth her energies in high and low places - to reform individuals, communities and government, and never rest until the kingdom and the greatness of the Kingdom under the whole heaven shall be given to the saints of the Most High God - until every form of inequity shall be driven from the earth. ${ }^{5}$

Henry Cowles, Finney's colleague at Oberlin later fully articulated the doctrine of postmillenium in his twenty three essays on the millenium. One important point

\footnotetext{
${ }^{3}$ Letter of 5 March 1743/4 to William McCulloch, reprinted in Jonathan Edwards, The Great Awakening, Works of Jonathan Edwards, edited by C.C. Goen (New Haven: Yale University Press, 1972), 4:560, As quoted by Donald W. Dayton, The Theological Roots of Pentecostalism (Peabody, MA: Hendrickson Publishers, 1996), 154.

4 Dayton, 155.

${ }^{5}$ Charles G. Finney, Reflections on Revival, compiled by Donald W. Dayton (Minneapolis: Bethany Fellowship, 1979), As quoted by Dayton, 155.
} 
developed by Cowles in his post-millennial eschatology is the role of the Church as the ushering agent in the millennium. Dayton says that Cowles "polemicizes against those who 'think God will bring in the millenium by a sort of miracle and chiefly without human agency'."6 In other words, for Cowley, the Millenium will tarry if the church fail to do her responsibility.

But the Oberlin' postmillenial doctrine faced a serious problem when the slavery controversy reached its climax in the Civil War. Internal tension occurred since the Oberlin's commitment to anti slavery came into conflict with its commitment to pacifism. Adherents to Oberlin's theology had to choose between peace and antislavery. Dayton says, "such choices seemed to postpone the millenium."7

When the Civil War ended and the victory over slavery came, the postmillennial optimism reached its peak. The most glorious day seemed to be at hand. In the words of Edward Beecher (1865), "Now God has smitten slavery into death, he has opened the way for the redemption and sanctification of our whole social system." 8

But the victory over slavery was not immediately followed by the Millenium. In fact, after the end of the Civil War, instead of a world growing better and better, there was a progressive decline. The heretical sects such as the Mormon (1830), Spiritualism (1848), Jehovah's Witnessess (1872), and Christian Science (1876) came into being. ${ }^{9}$ The old liberalism had gained a wider acceptance, even though it eroded the vitality of Christian faith. Besides, great waves of urbanization, immigration had created more economic and moral problem. The world really was growing worse and worse! As William W. Menzies points out:

The United States in the years between the Civil War and the close of the (nineteenth) century was in social and religious ferment. Moral, political, and economic corruption increased the stresses occasioned by urbanization, industrialization, and immigration. The greater denominations, successful in Christianizing the frontier, had become complacent and sophisticated, lacking the vision and vitality to meet the changing needs of a distressed populace. Varying degrees of accommodation to popular ideas, newly imported from

\footnotetext{
${ }^{6}$ Dayton, 157.

${ }^{7}$ Dayton, 160.

${ }^{8}$ Edward Beecher, "The Scriptural Philosophy of Congregationalis and Councils," Bibliotheca Sacra 22 (April 1865): 31. As quoted by Stanley J. Grenz, The Millennial Maze (Downers Grove, IL: IVP, 1992), 58

${ }^{9}$ Howard F. Voss, An Introduction to Church History (Chicago, IL: Moody Press, 1984), 148.
} 
Europe, which assaulted orthodox Evangelicalism, further weakened the great communions. ${ }^{10}$

Such situations had shattered the postmillennial vision, but had become a fertile soil for the flowering of the so-called dispensationalism or pretribulationalism.

\section{Defining Dispensationalism or Pretribulationalism}

Pretribulationism or dispensationalism is a variation within the body of premillenial eschatology. Its origin can be traced to the Plymouth Brethren in England and the influence of John Nelson Darby, an Irish Bible teacher. Darby developed a system of dispensation which is much similar to the work of Johannes Cocceius, a Dutch Calvinist, who "divided the one covenant of grace, which spans all of history from the fall to the eschaton, into several dispensations, and thereby described the history of redemption as a series of covenants." 11 The significance of Darby's system, however lies in "the conviction that God had two completely different plans operating in history: one for an earthly people, Israel, and the other for heavenly people, the church."12 God's plan for Israel had been "revealed through a series of covenants with Israel: the unconditional Abrahamic Covenant, the law-oriented Mosaic Covenant, the royal Davidic Covenant, and a new Messianic Covenant."13

When Israel rejected the suffering Messiah, Jesus Christ, God postponed his final plan for Israel and began "plan B", building a new and heavenly people - the Church. The Church, for Darby and other early dispensationalists, was not the spiritual Israel or the New Israel; she was a mystery and unpredicted surprise in the light of Old Testament prophecies. In the words of Clarence Larkin, "the prophets did not see the Church."

Since "plan A" (God's plan for Israel) and "plan B" (God's plan for the Church) could not run concurrently, God had to remove the Church from the scene of history before resuming His program with Israel. Such a rationale consequently led to the genesis of the most controversial and distinctive doctrine of dispensationalism - the

\footnotetext{
${ }^{10}$ William W. Menzies, Anointed to Serve (Springfield, MO: Gospel Publishing House, 1971), 33.

${ }^{11}$ Grenz, 60.

12 Timothy Weber, "The Dispensationalist Era," Christian History (Winter 1998) (http://www.christianitytoday.com/ch/61h/61h034.html).

13 Ibid.,
} 
secret, any-moment, pretribulational Rapture of the Church. What makes this doctrine distinctive is the idea of two-stage of the Second Advent. Earlier premillenialists generally believed that Rapture and the Second Coming was one event, occurring at the end of the Great Tribulation. But dispensationalists separated the Rapture from the Second Coming. The first will occur prior to the Great Tribulation and the second will occur at the end of the Great Tribulation; The first is a time when Christ will come for his saints; the second is a time when Christ will come with his saints.

Once the true church have been raptured, Darby and his fellowdispensationalists believe that Antichrist will rise and bring much horror to the people of God. Finally Christ together with His Saints will return to the earth, judge the nations of the world, conquer the Antichrist and throw Satan into a bottomless pit. Then, the Millenial Kingdom will begin. In the end of Millenium Satan will be released once more. He will deceive the nations and initiate a great war against Christ and his saints. Once more Christ and his saints will wage war against Satan and his followers resulting in the final victory and the total destruction of Satan. After that, the Last Judgment will come, followed by a new heaven and earth. Then the whole story of dispensations comes to an end.

The success of Dispensationalism

In the last quarter of $19^{\text {th }}$ century, premillianism gained initial success due to its involvement in the Bible Conference Movements. One of which, founded by a group of conservatives, finally headquartered at Niagara and was well-known as Niagara Bible Conference. One feature of Niagara Conference that lent itself to the development of premillenialism was its commitment to the authority of the Bible. Craig A. Blaising says, "At Niagara, the Bible was affirmed as the inspired Word of God and instruction was to be based upon it alone." 14 Such a feature certainly has promoted premillenialism who stood firmly for the inerrancy and biblical authority.

Under the leadership of premillianists, such as James Brookes, Niagara Bible Conference finally brought premillenialism into prominent place. However, there was still a problem due to the disagreement among premillenialists regarding the Rapture: On the one hand, William G, Moorehead, William J. Erdman, and Henry G, Weston held

\footnotetext{
${ }^{14}$ Craig A. Blaising, "Dispensationalism: The Search for Definition," in Dispensationalism, Israel, and the Church, edited by Craig A. Blaising and Darrell L. Bock (Grand Rapids, MI: Zondervan, 1992), 17.
} 
post-tribulationalism; On the other hand, C.I. Scofield, Arno C. Gaaebelein, and James Gray held pre-tribulationism.

After several years of controversy, Pre-tribulationalism finally won the contest and gained wider acceptance within the conservative wings of American churches. Two significant factors account for the success of pre-tribulationalism. First, key leaders of pre-tribulationalism, such as A.C. Gaebelien, C.I. Scofield, and Reuben A. Torrey had popularized its doctrine widely that it became the standard position of most Bible Conferences and Bible institutes. ${ }^{15}$ “Through the ministries of these school's graduates - pastors, evangelist, Bible teachers, missionaries, youth workers - dispensationalism spread." 16 Second, it was the publication of the Scofield Bible which soon dominated the conservative wings of American churches and become the badge of North American evangelicalism. ${ }^{17}$ The simplicity and easily digestible system provided by Scofield undoubtedly accounts for the great success of the Scofield Bible. As William and Robert Menzies expressed it, " Scofield dispensational system provided for lay people an easily understood method of Bible Study and by this means made the message of the Bible avalaible to the average person, a message easy to share with neighbors and friends." 18

By the eve of Pentecostalism, premillenialism or more specifically dispensationalism, began to fluorish in the soil of American evangelical churches. Thus, it is not surprising if the early Pentecostals who largely came out of pietistic evangelical tradition ${ }^{19}$ tended to fit their eschatology with methodologies and theological values of dispensationalism. As French L. Arington wrote: "Since Pentecostals as a whole shared the premillennial vision of the future, dispensationalism with its intense emphasis on futuristic eschatology had a strong appeal to them." 20

\footnotetext{
${ }^{15}$ Richard R. Reiter, "A History of the Development of the Rapture Positions," in The Rapture: Pre, -Mid-, or Post- Tribulational? (Grand Rapids, MI: Zondervan, 1984), 24.

${ }^{16}$ Weber,

${ }^{17}$ Reiter, 24.

${ }^{18}$ William W. Menzies, and Robert P. Menzies, Spirit and Power: Foundations of Pentecostal Experience (Grand Rapids, MI: Zondervan, 2000), 20.

19 Timothy P. Weber, "Premillennialism and the Branches of Evangelicalism," in The Variety of American Evangelicalism. edited by Timothy P. Weber (Downers Grove, IL: IVP, 1991), 12-13 classifies Methodists, Baptist, Oberlin Perfectionists, New School Presbyterian, holiness group, and later on, Pentecostals into Pietistic Evangelicals. Weber notes that the prevailing mood of premillenialism had been at the very heart of Pietistic evangelicals since in the late of $19^{\text {th }}$ century.

${ }^{20}$ Dictionary of Pentecostal and Charismatic Movements, s.v. "Dispensationalism," by French L. Arington.
} 


\section{EARLIEST PENTECOSTALS' PERSPECTIVES}

\section{ON ESCHATOLOGY}

The earliest Pentecostals believed that they were living in the Last Days. The outpouring of the Spirit in the beginning of $20^{\text {th }}$ century was understood as "evidence of the 'latter rain' or at least as sign of a last days' restoration of the Apostolic church prior to the return of Christ." 21 Divine healing, was understood not only as the demonstration of God's power over sickness, but as a sign of the Second Coming. ${ }^{22}$ Even, Speaking in tongues was not considered the central message of their movement, but rather a means by which the message (Jesus is coming soon) was propagated. ${ }^{23}$ As Vinson Synan says, “...despite the movements's association with tongues ever since that centennial prayer meeting, early Pentecostalism was less a tongues movement and more a Jesus-is-

\footnotetext{
${ }^{21}$ Sheppard, 5.

${ }^{22}$ As the Apostolic Faith, May 1907, expressed it in a very beautiful song,

Go into all the world My Saints,

Tell them that Jesus is coming

Preaching, and teaching, and healing the sick,

Tell them that Jesus is coming.
}

${ }^{23}$ Charles F. Parham, for example believed in the missionary purpose of the gift of tongues which was necessary
to make possible the fulfillment of the last sign of the end. In Topeka Journal 7 (January 1901): 4, he wrote:

We have for long believed that the power of the Lord would be manifested in our midst and that power would be given us to speak other languages, and that the time will come when we will be sent to go into all nations and preach the gospel, and that the Lord will give us the power of speech to talk to the people of the various nations without having to study them in schools.

William J. Seymour and the Azusa Street participants also linked the theme of imminent Second Coming to the missionary purpose of the gift of tongues:

The Gospel, the full Gospel of Jesus must be preached in all the earth for a witness then shall the end come (The Apostolic Faith, September 1907, p. 1)

Many are the prophesies spoken in unknown tongues and many the visions that God is giving concerning His soon coming, The heathen must first receive the Gospel. One prophecy given in an unknown tongue was interpreted, "The time is short, and I am going to send out a large number in the Spirit of God to preach the full gospel in the power of the Spirit. (The Apostolic Faith, September 1906, p. 1). 
coming-movement."24 In short, we can say that the central feature of earliest Pentecostal message is "Jesus is coming soon." 25

With this information in mind, we may now turn two earliest Pentacostals' position on eschatology as being reflected in the writings of Charles Fox Parham and Azusa Street Publications.

\section{Charles Fox Parham}

Biographical Sketch

A study of earliest Pentecostal eschatology should begin with Charles Fox Parham, for he was the first leader of the revival and continued to hold prominent place in it until his death in 1929. Parham was born in Muscatine, Iowa on June 4, 1873,educated for three years at Soutwest Kansas College (1890 -1893) married Sarah Thistlethwaite in 1896 and together with her founded Beth-el Healing Home in Topeka in 1898. This free of charge healing home provided appropriate surroundings for those who sought a divine cure. In October 1900 Parham opened free of charge, "faith based" Bible school -Bethel Bible College - with 40 students enrolling. Out of this school, the Modern Pentecostal Revival began when one of the students, Agnes Ozman, on January 1,1901 , experienced speaking in tongues as a result of specifically seeking a baptism in the Holy Spirit with the expectation of speaking in tongues. Parham himself experienced speaking in tongues on January 3, 1903. After three years experiencing difficult situation due to negative publicity and a small numbers of followers, Parham gained a significant success with the outbreak of revival in Galena, Kansas in late 1903. The success continued and reached its peak by mid 1906. But since 1907 Parham's reputation had dropped, partly due to charges of moral scandals. In 1929 he died as an almost unknown person among the second generation of Pentecostals. ${ }^{26}$

\section{Parham's Eschatology}

Much of Parham's eschatology is found in his book A Voice Crying in the Wilderness (1902). He certainly disdained postmillenialism which he considered a sort of deception.

\footnotetext{
${ }^{24}$ Vinson Synan, "The Second Comers," Christian History (Winter 1999) http://www.christianitytoday.com/61h/61h038.html)

${ }^{25}$ Robert M. Anderson, Vision of the Disinherited: the Making of American Pentecostalism (Peabody, MA: Hendrickson Publisher, 1992), 97.

${ }^{26}$ See Dictionary of Pentecostal and Charismatic Movements, s.v. "Parham, Charles Fox," by J. R. Goff, Jr; Klaude Kendrick, The Promise Fulfilled: A History of Modern Pentecostal Movement (Springfield, MO: Gospel Publishing House, 1961), 37, 45-46, 48, 52-54.
} 
The Post millennial theory of Christ' coming, has little effect to better condition of the Church. In that day these false shepherds will have little consolation for their poor deceived followers, who heard from Sunday to Sunday that the world was getting better and better, and in a short time they would enter the golden Age, at the close of which Christ would come to find that they (the Church) had gotten the world all converted and ready for His coming.

What blindness, what delusion, when today they are losing on every hand, people turning from them in streams to all manner of religious and agnostic organizations... ${ }^{27}$

His acceptance of the dispensational hermeneutics is equivocal. On the one hand, in matters of end-times events, he can sound typically dispensational, for example, the removal of Man-Child in the Rapture prior to the Great Tribulation period of seven years; the rule of Antichrist during the Great Tribulation that causes many saints die due to their refusal to accept the Mark of the Beast ; the Battle of Armageddon, in the Northwest of Jerusalem, between the King of South, that is the Antichrist who declares himself as Christ, with the endorsement of Roman Papacy and the King of South, that is the Czar of Russia; the Second Coming of Christ, resulting in the splitting of the Mount Olives and the destruction of all the fighting forces of the world; the literal millennial kingdom, a time when the Devil is bound for a thousand years, a time when perfect peace, happiness, and prosperity prevails all over the earth; the "White Throne Judgment", a work-based judgment performed by Christ. ${ }^{28}$

On the other hand, this sharp line begins to blur when he develops his obscure distinction between the Body and the Bride, the Man-Child, and the saints. The Body, for Parham is the true Church whose members, after receiving the seal of God through the Baptism in the Spirit, will "escape the power of the Antichrist as well as the plagues and wraths." 29 In the redemption, the final "steps of grace" - the Body will have the glorious body. They will be "like Jesus, have power to appear and disappear at will"30

\footnotetext{
${ }^{27}$ Charles F. Parham, Voices in the Wilderness (Baxter Springs, Kansas: Apostolic Faith Bible College, n.d.). 124. The italics is mine.

${ }^{28}$ See Ibid., 86-138.

${ }^{29}$ Ibid., 123.

${ }^{30}$ Ibid., 70.
} 
While The Bride, for Parham, is

a small company One Hundred and Fourty-four Thousand, taken out of His Body (the Church), ... whose glory is of a different nature to that Body: Her clothing are all of wrought gold, being all glorious within (Ps. 45: 13), ${ }^{31}$

Prior to the Great Tribulation, this Bride will flee to the "wilderness" - that is a safe place in the land of Palestine provided by God. They will tarry for three and half years there before meeting the Lord in the mid-air at the personal coming of Christ. 32

The Man-Child is another select group of 144.000, taken out of the Bride. They are those who "reach the highest perfection attainable for human beings planned by God through the atonement of Jesus Christ." 33 Prior to the Great Tribulation the ManChild will be raptured and "will rule the nations in the 1000 byears reign of Christ." 34 They are called "the first fruit unto God, ... the overcomer." 35

The saints, on the contrary, are "foolish virgins" who get saved and sanctified but are not "looking for or expecting their Lord's return." 36 Therefore, they will be left behind and experience the horror of the reign of Antichrist. The only way for them to share in the final resurrection and the blessing of the Millenial kingdom is to refuse the "Mark of the Beast". This means a willingness and readiness to be a martyr. ${ }^{37}$

Parham's understanding of the Body, the Bride, the Man-Child, and the saints is distinctive and alien to dispensationalism. While Parham speculates that Man-Child is the only raptured saints, dispensationalist considers that the Man-Child is Christ. ${ }^{38}$ While Parham refuses to equate the Body (the Church) with the Bride, dispensationalist identifies the Church as the Bride. ${ }^{39}$ While Parham's eschatology describes three modes of exemption from the Great Tribulation period for the blessed ones: The Rapture, for the Man-Child, the "wilderness" protection for the Bride, and the glorious body for the the Body, dispensationalist generally has only one mode of exemption, namely the

\footnotetext{
${ }^{31}$ Ibid., 86-87.

${ }^{32}$ Ibid., 87-89.

${ }^{33}$ Ibid., 90.

34 Ibid., 90.

35 Ibid., 90.

${ }^{36}$ Ibid., 124.

${ }^{37}$ Ibid., 124-126.

${ }^{38}$ See for example, Clarence Larkin, The Book of Revelation (Philadelphia, PA: Erwin W. Moyer Co. Printers, 1919), 93.

${ }^{39}$ See for example, Clarence Larkin, Dispensational Truth (Park Ave, PA: Clarence Larkin Est, 1920), 76.
} 
Rapture. ${ }^{40}$ While Parham allows a select company of the Body (the true Church), namely the Bride, will go through the Great Tribulation period, but be totally protected from the power of Antichrist and God's wrath, dispensationalist does not allow the true church go through the Great Tribulation period. ${ }^{41}$ Finally, a prominent place of Baptism in the Holy Spirit in Parham's soteriology and eschatology - that is "a-must-experience" for those who want to be exempted from the Great Tribulation shares not affinities with the dispensational theology.

It is clear from the synopsis of Parham's eschatology that he was peculiarly attuned to the demand of "the present market" - a growing popularity of dispensationalism But Parham's personal experience, inadequate theological training, and mixed theological tradition (Congregationalism, Methodism, Quakerism, and Holiness) had prevented him from cloning the dispensationalism. As Robert M. Anderson brilliantly expresses it:

Many of the notions woven into the fabric of Parham's scheme many be traced back to very ancient times, but it is likely that Parham derived them from the religious milieu of his own days, corroborating and modifying them in the light of his own experience and his study of the Bible. His lack of religious training in childhood, the influence of his father-in-law's eccentric Quakerism, and his shifts from Congregationalism to Methodism to Holiness had left him singularly free from inhibitions about innovating and appropiating ideas from various Christian and pseudo Christian traditions. ${ }^{42}$

\section{the Azusa Street Revival}

William Joseph Seymour, a son of former slaves, Simon and Philis Seymour, a man without the use of his left-eye, a former student of Charles Parham arrived at Los Angeles on February 22, 1906, and began to conduct prayer meetings two days later on Santa Fee. Due to Doctrinal disagreement regarding the speaking in tongues Seymour moved to the house of Richard and Ruth Ashberry at 214 Bonnie Brae and began a prayer meeting there. On April 9, 1906, seven attendants of the prayer meeting were

\footnotetext{
${ }^{40}$ Ibid., 78-80.

${ }^{41}$ Ibid., $78-80$.

${ }^{42}$ Anderson, 86-87.
} 
baptized in the Holy Spirit and began to speak in tongues. What was happening had attracted so much attention that the service had to be moved to a larger building at 312 Azusa Street on April 14, 1906. There, the revival continued with increasing force, attracting many visitors from inside and outside the country. Those visitors undoubtedly helped to spread the "Azusa Streets Fire" nationally and internationally. ${ }^{43}$ The impact of the revival was so significant that Cecil M. Robeck writes, "Indeed, nearly every Pentecostal denomination in the U.S traces its roots in some way or other to the Apostolic Faith at 312 Azusa Streets." 44

Indeed Seymour and the Azusa Street participants did not produce a systematized theological treatise. But they published a periodical titled The Apostolic Faith, between September 1906 and May 1908. The complete set of the Apostolic Faith consists of 13 papers, primarily documenting testimonial reports but without ignoring sermons, bible studies, songs, and poems. From these written sources, the study of the Azusa Street' eschatology begins.

\section{The Azusa Street's Eschatology}

Undoubtedly the Azusa Street's participants developed such eschatology that was typically dispensationalism. They believed in two-stage of the Second Advent,

There will be two appearances of Jesus under one coming. The first appearance is called the Rapture, when he comes as a thief in the night and catches away his bride; the second is called the Revelation when he shall come with ten thousands of His Saints and destroy the wicked with the brightness of His coming, ... ${ }^{45}$

the reign of Antichrist and the Great Tribulation period,

Antichrist will reign during the tribulation and everything will be controlled by him and by false prophet, when they succeeded in uniting the whole world in acknowledging the antchrist. Those that acknowledge him will be permitted to buy and to sell, but those that stand faithful to the Lord Jesus and testify to the Blood, will be killed for the word of their testimony. ${ }^{46}$

\footnotetext{
${ }^{43}$ See, Kendrick, 66-68; Dictionary of Pentecostal and Charismatic Movement, s.v. “Azusa Street Revival,' by Cecil M. Robeck; "Seymour, William Joseph,” by H. Vinson Synan.

${ }^{44}$ Robeck, 35.

45 _. "Notes on the Coming of Jesus," The Apostolic Faith ( September 1907): 4

${ }^{46}$ William J. Seymour, "Behold the Bridegroom Come, “ The Apostolic Faith (January 1907): 2.
} 
the literal millenial kingdom:

That will be the millenial age (Jude 14,15). The saints who have part in the first resurrection will return with Jesus and reign over unglorified humanity ... That is a time when lion and calf shall lie down together and a little child shall lead them (Isa 11: 6-9). ${ }^{47}$

The throwing of Satan into the Lake of fire and the creation of the new heaven and earth after the end of the Millenium:

In the millennial age, we shall gave great glory, but it will be greater glory when Satan has been judged and cast into the lake of fire; and the meek, the justified soul shall inherit the earth and we shall be living in the new heaven and the New Jerusalem. ${ }^{48}$

Despite much affinity with Dispensationalism, one must acknowledge that the Azusa Street Participants understood the Baptism in the Holy Spirit as the pre-requisite to participate in the Rapture of the church. William Seymour for example, spoke of the raptured church as "the wise virgins" and the lef-behind church as "the foolish virgins" who failed to provide enough "oil".

....Above all, we want to get the oil, the Holy Ghost. Every Christians must be baptized with the Holy Ghost for himself. Many poor soul in that day will be awfully disappointed. May we seek Him today, the baptism with the Holy Ghost and fire. Now it is to buy the oil!; that is, by tarrying at the feet of the Lord Jesus and receiving the baptism with the Holy Spirit. ${ }^{49}$

This idea of course is alien to Dispensationist, but not to Charles F. Parham. Some years earlier, as mentioned above, Parham linked pneumatology (Baptism in the Holy Spirit) to eschatology (exemption from the horror of Antichrist and tribulation). In this regard, Seymour as the former student of Charles Parham seems to retain what his teacher was saying.

\footnotetext{
47 , "The Millennium," The Apostolic Faith (September 1906): 3

$48 \overline{\text { Ibid., } 3 \text {. }}$

${ }^{49}$ Seymour, 2.
} 
Ambrose B. Crumpler and the Pentecostal Holiness Church

Ambrose Blackman Crumpler was born in 1863 near Clinton, North Carolina. He got converted in the late 1880s and received the second blessing - "the experience of entire sanctification" in 1890. At the beginning of his ministry, Crumpler joined Methodist Church, but withdrew from the church for refusing to stop preaching the doctrine of sanctification. In the spring of 1900 in Fayetteville, North Carolina, together with G.B. Cashwell and few other former Methodist ministers, Crumpler formed a new denomination called "The Pentecostal Holiness Church." In 1900, the word "Pentecostal" dropped resulting in the new name, "The Holiness Church." Synan says that "This step was taken because many members were using the term 'Pentecostal church: to identify themselves, rather than the more 'reproachful' term 'Holiness Church." 50 By 1902, under the leadership of Crumpler, the denomination had grown significantly. In 1906, a wave of controversy began to sweep the new denomination due to the introduction of Pentecostalism by G.B. Cashwell who taught that glossolalia was the only initial physical evidence for the Baptism in the Holy Spirit, an idea which was rejected by Crumpler. The controversy reached its peak in 1908 convention, leading to the stepping down of Crumpler from the denomination. In 1908, under Cashwell's leadership, the denomination adopted a Pentecostal article of faith and in 1909 the adjective "Pentecostal" was finally restored to the name.

\section{.Pentecostal Holiness Church's Eschatology}

Pentecostal Holiness Church's eschatology undoubtedly owe an immense debt to Ambrose B. Crumpler for The Discipline of Pentecostal Holiness Church which serve as a basis of doctrinal unity within the denomination was largely written by him. The first edition of The Discipline, issued in 1902 has an article on eschatology, which states: THE SECOND COMING OF CHRIST.

According to the Scriptures we look for the personal pre-millennial return of Jesus to this earth to raise the holy dead, translate the holy living, to take or yield vengeance on them that know not God, in the "battle of that great day of God

\footnotetext{
${ }^{50}$ Vinson H. Synan, The Holiness-Pentecostal Tradition: Charismatic Movements in the Twentieth Century (Grand Rapids, MI: Wm. B. Eerdmans, 1997), 64.
} 
Almighty," to imprison the devil, and to reign over the whole earth for a thousand years; at the close of which the devil will be loosed for a little season, the wicked dead raised and the "last judgment" take place and the new heavens and new earth ushered in to abide forever. ${ }^{51}$

That the document espouses openly Premillenialism is without question. But one looks in vain from the first word to the last word of the document for a concern with the secret rapture of the church out of the world prior to the Great Tribulation. Does this statement reflect intentional ambiguity on the exact relation of the Rapture, the Great Tribulation and the Second Coming? It seems so! This is very well attested by the by the publication Constitution and General Rules of The Pentecostal Holiness Church issued in 1911. Point 7 of the Basis of Union clearly states, "We believe in the imminent, personal, premillennial second coming of our Lord Jesus Christ (1 Thes. 4: 15-18; Titus 2:13; 2 Peter 3: 1-4; Matt. 24: 29-44), and we love and wait for His appearing (2 Tim. 4: 8)."52 This statement is clearly premillenial, but not pretribulational. Thus it had made the essential component of dispensational eschatology dissolve in the early doctrinak belief of the Pentecostal Holiness Church.

III. EARLY PENTECOSTAL ESCHATOLOGY AFTER AZUSA STREET REVIVAL

D. Wesley Myland

Biographical Sketch ${ }^{53}$

\footnotetext{
${ }^{51}$ Ambrose B. Crumpler, The Discipline of Holiness Church (http://www.pctii.org/arc/1902.html] Search: January 8, 2001.

$52 \_$General Constitution Pentecostal Holiness Church [http://www.pctii.org/arc/1911.html]. Search: January 8, 2001

${ }^{53}$ Much of this biographical presentation is taken from Dictionary of Pentecostal and Charismatic Movements, s.v. "Myland, David Wesley," by E.B. Robinson and Three Early Pentecostal Tracts, edited and with a Preface by Donald W. Dayton (New York \& London: Garland Publishing, Inc, 1985), viii-ix.
} 
D. Wesley Myland was born in Ontario, Canada, in 1858. His early denominational identification was with the Methodist Episcopal Church. After being healed miraculously, he preached divine healing in addition tot he second blessing of entire sanctification. This of course was not in line with Methodist' teaching. As a result, he moved to the Christian and Missionary Alliance (CMA) in 1890.

After having heard the Azusa Street revival, he began to seek the Pentecostal experience. Several months later he received baptism in the Holy Spirit, in addition to his seventh divine healing in November 1906. As a result, he began preaching Pentecostal message. When CMA decided to break with Pentecostalism in 1912, Myland left, but never loosing contact with, the CMA. Upon leaving the CMA, Myland was involved a while with the Gibeah Bible School at Plainfield Indiana. There, he taught and ordained J. Roswell Flower and Alice Reynold Flower who were involved in establishing the Assemblies of God and at the same time founded and becme the general superintendent of the Association of Christian Assemblies. Unfortunately the organization ceased to function in 1914.

Myland never affiliated himself with any Pentecostal denomination. Even at the point his death, he maintained his credentials with the Methodist church. But he gained favourable regard from early Pentecostal leaders, especially from AG circles. After leaving Gibeah, Myland taught at what is known today as Beulah Heights Bible College, pastored and pionereed several churches before his death in 1943.

Besides being widely known as an evangelist, author and singer of gospel songs, Myland was prolific writer. Among his publications is the Latter Rain Covenant and Pentecostal Power from which we get primary source for studying Myland's eschatology.

$$
\text { Myland's Eschatology }
$$

Myland's acceptance of the dispensational eschatology is also equivocal. On the one hand, in matters of the end times events, he can sound typically dispensationalist, for example, regarding the Second Coming Myland believed in a two-stage of the Second Coming: the Parousia and the epiphany, separated one another by a seven years period of tribulation 
Four Greek words are rendered "coming" but they are different events. This one is parousia which occur seven years before the epiphany, The epiphany is sometime rendered the forth-shining, every eye shall see Him; but the parousia is a secret coming; nobody knows it but those who are ready. ${ }^{54}$

On the other hand, this sharp line begins to blur when he called the Church as a spiritual Israel: "He will come to spiritual Israel, the Bride, in Parousia secretly, to catch them away. Spiritual Israel wont'know much about the dark part of the night, that will come at the end of the seven years in His epiphany, ...." 55

Myland's designation of the Bride (Church) as "a spiritual Israel" that implies a continuity between the natural Israel and the Church certainly alien to dispensationalism. Charles C. Ryrie, a prominent theologian of dispensationalism, for example speaks of distinction between Israel and the Church:

Use the words Israel and Church shows clearly that in the New Testament national Israel continues with her own promises and the Church is never equated with a so-called "new Israel" but is carefully and continually distinguished as a separate work of God in this age. ${ }^{56}$

Myland's hermeneutical approach may account for his diversion from classical dispensational position. The Scripture, for Myland, has not only literal aspect, but also spiritual and dispensational aspect. In other words, Scripture could and should be read literally (historically), typologically (spiritually) or prophetically (dispensationally).

We see therefore in this promise that this Latter Rain Covenant ... has three-fold application ... in its working and fulfillment: first, historical or literal in reference to the Hebrews and their land, Palestine; second, typical as it applies to the Christian life, and third, prophetical or dispensational in the preparation of God's people in the different ages thus bringing in the perfect age when there shall be

\footnotetext{
${ }^{54}$ D. Wesley Myland, The Latter Rain Covenant and Pentecostal Power (Chicago, IL: The Evangel Publishing House, 1910), 140.

${ }^{55}$ Ibid., 132.

${ }^{56}$ Charles C. Ryrie, Dispensationalism Today (Chicago, IL” Moody Bible Institute, 1965), 140.
} 
what this Latter Rain Covenant eventuates in, the perfect millennial age, :the days of heaven on earth." 57

This of course is different from the hermeneutics of dispensationalism that holds a consistently literal hermeneutics. As Ryrie says, "Consistenly literal or plain interpretation is indicative of a dispensational approach to the interpretation of the Scripture." 58 Thus, in case of relation of the Church to the concept of the seed of Abraham, on the one hand, Myland considered the Church as the spiritual Israel, based on the spiritual reading of the terms "the seed of Abraham." 59 On the other hand, dispensationist believed that "the Church is a seed of Abraham, but this does not mean that the Church is Israel," based on the plain, literal reading of the Scripture. 60

\section{Daniel Warren Kerr}

\section{Biographical Sketch}

Daniel Warren Kerr was born in 1856. His early denominational identification was with Evangelical Association and Christian Missionary Alliance (CMA). In 1907, Kerr and his wife received Pentecostal experience while attending the Beulah Park camp meeting east of Cleveland. Kerr died in 1927 and is buried in Cleveland.

D.W. Kerr was "an able pastor, early Pentecostal publisher and editor, and a fine teacher." 61 Besides, he was "one of the most influential founding fathers in the Assemblies of God." 62 The statement of Faith approved at the 1916 Council, according to Wilson, "was largely the work of D.W. Kerr." 63 Kerr was also one of the men behind the founding of three Assemblies of God schools: Bethany College of the Assemblies of God (1919), Southern California College (1920), and Central Bible College (1922) ${ }^{64}$ and prolific writers. He wrote several books and many articles for Pentecostal Evanges and Latter Rain Evangel. Among his publication, Chart of the Ages or Great Events and Crises in Bible History (1920) and The Two-fold Aspect of Church Life: Will the Church Go

\footnotetext{
${ }^{57}$ Myland, 23.

${ }^{58}$ Ryrie, 46.

${ }^{59}$ Myland, 134.

${ }^{60}$ Ryrie, 148.

${ }^{61}$ Menzies and Anderson, 8.

${ }^{62}$ Ibid., 8.

${ }^{63}$ Lewis Wilson, “The Kerr-Pierce Role in A/G Education,” Heritage (Spring 1990): 6.

${ }^{64}$ Menzies and Anderson, 9; Dictionary of Pentecostal and Charismatic Movements, s.v. "Kerr, Daniel Warren," by C.E. Jones.
} 
Through the Tribulation (1919), are especially important for studying Kerr's distinctive eschatology.

\section{Daniel W. Kerr's Eschatology}

Just as Parham and Myland's, Kerr's acceptance of dispensational hermeneutics is equivocal. On the one hand, in matters of understanding the plan and purpose of God in the Ages, he can sound typically dispensational, for example, when designing a "Larkin-like" of dispensational chart, Kerr divided the whole history into 10 ages "broken down into two prehistoric ages followed by seven dispensations and eight eternal period called 'the Day of God' of 'Future ages." 65 On the other hand, this sharp lines begins to blur when his chart clearly shows two Raptures, one at the beginning of Tribulation and one at the end of Tribulation. This of course is alien to classical dispensational position that purely holds pre-Tribulation Rapture.

Kerr's two Rapture position then was expounded in his sermon preached at General Council on September 1919 in Cleveland Ohio, whose first part then was published in Latter Rain Evangel, titled The Two-fold Aspect of Church Life: Will the Church Go Through the Tribulation in October 1919.

As the title suggests, Kerr believes that the first aspect of the Church life deals with the plan and the purpose of God concerning the Church, namely the unity and the perfection of the church as originally outlined in Acts 15:12,13, and as indicated by Paul in Ephesians 4: "Till we all come into the unity of the faith and of the knowledge of the Son of God, unto a perfect man, unto the stature of the fullness of Christ." 66 But, the second aspect of the Church Life, "the church as a disjoined, dislocated and divided body, no longer responsive in all its part to the Head, Christ ,"67 has failed to overcome the "gates of hell" (Satan and his angels) resulting in the change of God's original plan, but not His purpose.

The facts remains, the church failed in the "evil day" (see Eph. 6:23) and her failure is "the heart failure." "I have somewhat against thee because thou hast left thy first love. Remember from whence thou are fallen!" (Rev 2:5) Jesus the Head of the church recognizes a condition which was brought about by the opposition of the forces of hell under the direction of the devil, through his

\footnotetext{
${ }^{65}$ Menzies and Anderson, 11.

${ }^{66}$ Daniel W. Kerr, "The Two-Fold Aspect of the Church Life: Will the Church Go through the Tribulation?" Paraclete (October 1919): 2-3.

${ }^{67}$ Ibid., 3
} 
strategies, undermining her confidence, her faith, and love in the Lord Jesus Christ. The Church left her first love and the program was changed. His purpose has not changed for the gates of hell could not prevail against it, but His original plan according to which He intended to carry out His program, is changed. 68

The tension between "what the church is" and "what the church ought to be" which was in Kerr's mind had compelled him to develop three distinctive bodies: the man-child, the woman, and the remnant, based on the biblical reference of Revelation 12 .

The man-child is "a little church within the church." 69 They are the overcomers in the church and "shall be kept from the hour of temptation or trial that shall come upon all the earth, that is from the great tribulation,." ${ }^{70}$ and be given authority to rule the nations. The reason for this privilege was:

that it has masculine qualities and that these qualities are its distinctive qualities are its distinctive characteristics. It has gotten rid of all its effeminacy. It has the moral and physical stamina of Jesus Christ, and is qualified in every way to take the throne with Jesus, and to take the rod of iron which He gives and to go forth to conquer the nations and bring them as a footstool for His feet. ${ }^{71}$

On the other hand, two other distinctive bodies, the woman and the remnant are the rest of the church as opposed to the man-child, the full overcomers, who will have to go through the Great Tribulation. The woman, however, will be protected by God some where in the "wilderness" for three and half years. ${ }^{72}$ But the remnant will have to experience martyrdom under Antichrist. ${ }^{73}$

From this understanding, we can conclude that three distinctive classes within the church will meet God at different times. As the end of Kerr's first part sermon indicates it

Here then are three distinct classes into which the church fell, because of "heart failure" toward Head and Husband. "Every man in his own order (rank)" will ultimately reach the place and position which was given him by the Father, who

\footnotetext{
${ }^{68}$ Ibid., 4.

${ }^{69}$ Ibid., 5

${ }^{70}$ Ibid., 5.

${ }^{71}$ Ibid., 5

72 Ibid., 5.

${ }^{73}$ Ibid., 6. The italics is mine.
} 
"hath chosen us in Christ before the foundation of the world," but not all will reach the goal at the same moment of time, but at different intervals and in different sections, as the next Bible study will show. ${ }^{74}$

Thus, the man-child certainly will be raptured before the Great Tribulation, and the remnant will reach God through martyrdom, but when will the women be caught up after being well taken care of and nourished by the Lord? Even though Kerr's answer is not found, for the sequel of the sermon that is expected to have the answer, is not available, we can be pretty much sure that it will happen in the end of the Great Tribulation, as his chart indicates. ${ }^{75}$

In short, we can say that Daniel W. Kerr's eschatology is distinctive. He, as all dispensationalists, believed in the imminence of the blessed hope, the rapture of the saints. But he developed such a novel theory of two raptures that was alien to dispensationalism.

The earliest version of the Assemblies of God

16 Statement of Fundamental Truths (1916)

The earliest version of the Assemblies of God 16 Statement of Fundamental Truths also shows ambiguities concerning the exact relation of the Rapture, the Tribulation, and the Second Coming, while retains the idea of literal millennial Kingdom. Point 13, 14 which are the eschatology section in the Statement of Fundamental Truth does not even mentions explicitly, "tribulation" and "rapture" terminology, while speaks explicitly of the earthly millennial kingdom.

13. The Blessed Hope

\footnotetext{
${ }^{74}$ Ibid., 6.

${ }^{75}$ Menzies and Anderson, 15.
} 
The resurrection of those who have fallen a sleep in Christ and their translation together with those who are alive and remain unto the coming of the Lord is the imminent and blessed hope of the Church. I Thess, 4:16; Romans 8:23; Titus 2:18; 1 Cor 15: 51, 52.

\section{The Millennial Reign of Jesus}

The revelation of the Lord Jesus Christ from heaven, the salvation of nation Israel, and the millennial reign of Christ on earth are the Scriptural promises and the world's hope. 2 Thess. 1:7; Rev. 19:11-14; Romans 11: 26, 17; Rev 20: 1-7.76

Now, compare this with a version of 16 Fundamental Truth affirmed by General Council of Assemblies of God in 1969. Point 13 is basically the same with the earlier version, but there is a major modification on point 14 . Here the idea of two-stage of the Second Coming is explicitly mentioned: "the rapture" and "the visible return of Christ with His Saints".

\section{The Blessed Hope}

The resurrection of those who have fallen a sleep in Christ and their translation together with those who are alive and remain unto the coming of the Lord is the imminent and blessed hope of the church (1 Thess. 4:16,17; Romans 8:23; Titus 2:13; 1 Cor. $15: 51,52$ )

14. The Millennial Reign of Christ

The Second coming of Christ includes the rapture of the saints_which is our blessed hope, followed by the visible return of Christ with His saints to reign on the earth for one thousand years (Zech 14:5; Matt. 24:27, 30; Revelation 1:7; 19:11-14; 20:1-6). This millennial reign will bring the salvation of national Israel

\footnotetext{
${ }^{76}$ As recorded by William W. Menzies and Stanley M. Horton, Bible Doctrines: A Pentecostal Perspective (Springfield, MO: Logion Press, 1994), 266.
} 
(Ezekiel 37:21, 22; Zephaniah 3:19, 20; Romans 11:26, 27) and the establishment of universal peace (Isaiah 11:6-9; Psalm 72: 3-8; Micha 4: 3, 4). ${ }^{77}$

The genesis of point 14 in the latter version of 16 Fundamental Truths certainly cannot be separated from the statement of General Presbytery approved by the General council of Assemblies of God in September 1937 that explicitly opposed to the teaching of post-tribulation rapture.

Whereas, the General Council has declared itself in the Statement of Fundamental Truths that it holds to the belief in the imminent coming of the Lord as the blessed hope of the Church, and

Whereas the teaching that the Church must go through the Tribulation tends to bring confusion and division among the saints; therefore,

We recommend that all our ministers teach the imminent coming of Christ, warning all men to be prepared for that coming, which may occur at any time, and not lull their minds into insecurity by any teaching that would cause them to feel that certain events must occur before the Rapture of the saints.

Furthermore, We recommend that should any of our ministers hold to the post-Tribulation doctrine, they refrain from preaching and teaching it. Should they persist in emphasizing this doctrine to the point of making it an issue, their standing in the fellowship will be seriously affected. ${ }^{78}$

Thus, we can see a changing perspective on eschatology. While the earliest version of 16 Fundamental Truths seems to be closer to non-dispensational document, the latter version of 16 Fundamental Truths seems to be closer to dispensationalism. While the earliest version seems to be open to divergent interpretation, and so allowed room for a group of Assemblies of God minister to espouse eschatological views other than pretribulation rapture, the latter version explicitly prohibited any eschatological views other than pretribulation rapture.

\footnotetext{
${ }^{77}$ As recorded by William W. Menzies, Anointed to Serve (Springfield, MO: Gospel Publishing House, 1971), 390. The italics mine.

${ }^{78}$ As quoted by Menzies and Anderson, 11-12.
} 
Why did such a narrowing perspective occur? Timothy Weber's study on American dispensationalism may throw a light to understand what was happening. Weber points out that World War I undoubtedly encouraged dispensationalist to press their doctrine which seemingly failed to gain prominent place in the end of $19^{\text {th }}$ century due to the absence of consensus regarding the exact nature of Second Coming among fundamentalist. The result is that after World War I, fundamentalism become "fully dispensationalist." This then encouraged popular revivalist to include "the rapture" in their sermons and teaching. ${ }^{79}$

Most probably, Assemblies of God leaders were absorbed in the prevailing eschatology during that time resulting in the formulation of the strict doctrine, namely, a pre-tribulation rapture that typically marked dispensational eschatology.

\section{AFTERWORDS}

\section{Conclusion}

From the presentation above, we can conclude that, first, the early Pentecostal eschatology (at least prior to 1920) was certainly premillenial, but not necessarily pretribulational rapture, as held by dispensationalist. Second, there was a rich diversity in the early Pentecostal views on eschatology. This however began to change after the World War I. The dominance of dispensationalism within the American evangelical churches had compelled Pentecostals to narrow their eschatological perspective to a pretribulation rapture. This is very well attested by the publication of Pentecostal documents after 1935 which showed a heavy reliance to dispensational system. ${ }^{80}$

The Future of Pentecostal Eschatology:

A Clear and Present Danger

\footnotetext{
${ }^{79}$ See Sheppard, 9

${ }^{80}$ See for example, Frank M Boyd.,Ages and Dispensations (Springfield, MO: Gospel Publishing House, n.d); J. Naver Gortner. Studies in Revelation, An Introduction by Frank M. Boyd. (Springfield, MO: Gospel Publishing House, 1948); Myer Pearlman. Knowing the Doctrines of the Bible (Springfield, MO: Gospel Publishing House, 1937); Ernest S. Williams. Systematic Theology. (Springfield, MO: Gospel Publishing House, 1953); P.C. Nelson, Bible Doctrines (Springfield, MO: Gospel Publishing House, 1948)
} 
During 1950's, George E. Ladd of Fuller Seminary wrote Crucial Questions About the Kingdom of God (1952) and The Blessed Hope (1956). These two books served as a main catalyst in the resurgence of historic (post-tribulational) premillennial eschatology among evangelicals. Even though Ladd's exegetical skill was not able to convince Pentecostals to ignore their pretribulation rapture eschatology, it indeed brought a significant modification on Pentecostal eschatology. Stanley Horton, ${ }^{81}$ a prominent Pentecostal scholar, for example, has developed non-dispensational preTribulation Rapture eschatology.

Recently, along with some significant adjustment within dispensationalism itself, ${ }^{82}$ younger Pentecostal scholars, such as Timothy P. Jenney ${ }^{83}$ and Robert $\mathrm{P}$, Menzies $^{84}$, take another step to drift away from their 'inherited' pretribulation rapture eschatology. It seems that the increasing sophistication of exegetical methods has caused them to grapple with their system and then to modify their eschatology in order to bring more biblical and eschatology to their community.

Interestingly, even though in the scholarly community, pretribulational rapture eschatology is getting less influential, in the popular lever its influence remains strong. Best-sellers books, such as Late Great Planet Earth by Hal Lindsay and Left Behind by Tim La Haye are evidence that Pre-Tribulational Rapture eschatology is still gain much public attention in the last 40 years. However, in the future, Jenney and Menzies' influence cannot be underestimated. Their students, who mainly come from Asian context, are potential propagators of historic premillennial eschatology which seems to be more relevant to their context - suffering, poverty, social injustice and religious persecution, and exegetically intelligible. There is a potential danger here. The clashing of interest may result in destructively dividing the Pentecostal movement. Thus preventive actions needs to be taken. Here, we may learn from what our founders did in the first two decade of the 100 years modern Pentecostal history. While maintaining

\footnotetext{
${ }^{81}$ See Stanley M. Horton. Our Destiny: Biblical Teachings on the Last Things(Springfield, MO: Logion Press, 1996); Systematic Theology ( Springfield, MO: Logion Press, 1994).

82 See Craig A. Blaising and Darrell L. Bock. Dispensationalism, Israel and the Church (Grand Rapids, MI: Zondervan, 1992)

83 Timothy P. Jenney. "Revelation." in Full Life Bible Commentary to the New Testament: An International Commentary for Spirit-Filled Christians. Edited by Roger Stronstad and French L. Arington (Grand Rapids, MI: Zondervan, 1999), 1618-1619.

${ }^{84}$ Robert P. Menzies. Class notes on Revelation. APTS, Summer 1996
} 
the core, namely "Jesus is coming soon," they allowed room to espouse diverse opinions regarding the peripheral (the exact relation of the rapture, the Tribulation, and the Second Coming). So, "Unity in the Spirit, but diversity in eschatology" can be sustained.

\section{BIBLIOGRAPHY}

Constitution and General Rules of The Pentecostal Holiness Church [http://www.pctii.org/arc/1911.html] (Search: January 8, 2001) . "The Millennium." Apostolic Faith (September 1906): 3 . "Notes on the Coming of Jesus." The Apostolic Faith (September 1907): 4 . "Jesus is Coming" The Apostolic Faith (May, 1907): 2.

Anderson, Robert M. Vision of the Disinherited: the Making of American Pentecostalism. Peabody, MA: Hendrickson Publisher, 1992.

Blaising, Craig A. "Dispensationalism: The Search for Definition," in Dispensationalism, Israel, and the Church, edited by Craig A. Blaising and Darrell L. Bock. Grand Rapids, MI: Zondervan, 1992.

Boyd, Frank M. ,Ages and Dispensations. Springfield, MO: Gospel Publishing House, n.d.

Crumpler, Ambrosse B. The Discipline of Holiness Church. [http://www.pctii.org/arc/1902.html] (Search: January 8, 2001)

Dayton, Donald W. Theological Roots of Pentecostalism. Peabody, MA: Hendrickson Publishers, 1996.

Ed. Three Early Pentecostal Tracts, with a Preface by Donald W.

Dayton. New York \& London: Garland Publishing, Inc, 1985.

Dictionary of Pentecostal and Charismatic Movement. S.v. "Dispensationalism," by French L. Arington.

. S.v. "Parham, Charles Fox," by J. R. Goff, Jr;

. S.v. "Azusa Street Revival," by Cecil M. Robeck.

S.v. "Seymour, William Joseph," by H. Vinson Synan. 
. S.v. "Myland, David Wesley," by E.B. Robinson . S.v. "Kerr, Daniel Warren," by C.E. Jones.

Gortner, J. Naver. Studies in Revelation, An Introduction by Frank M. Boyd. Springfield, MO: Gospel Publishing House, 1948.

Grenz, Stanley J. The Millennial Maze. Downers Grove, IL: IVP, 1992

Horton, Stanley M. Our Destiny: Biblical Teachings on the Last Things. Springfield, MO: Logion Press, 1996.

Jenney, Timothy P. "Revelation." in Full Life Bible Commentary to the New Testament: An International Commentary for Spirit-Filled Christians. Edited by Roger Stronstad and French L. Arington. Grand Rapids, MI: Zondervan, 1999.

Kendrick, Klaude. The Promise Fulfilled: A History of Modern Pentecostal Movement. Springfield, MO: Gospel Publishing House, 1961.

Kerr, Daniel W. "The Two-Fold Aspect of the Church Life: Will the Church Go through the Tribulation?" Paraclete (October 1919): 2-6.

Larkin, Clarence The Book of Revelation. Philadelphia, PA: Erwin W. Moyer Co. Printers, 1919. , Dispensational Truth. Park Ave, PA: Clarence Larkin Est, 1920.

Menzies, Glen W., and Gordon L. Anderson. "D.W. Kerr and Eschatological Diversity in the Assemblied of God.” Paraclete (Winter 1993): 8-16.

Menzies, Robert P. Class notes on Revelation. Asia Pacific Theological Seminary Baguio City Philippines, Summer 1996

Menzies, William W.and Robert P. Menzies, Spirit and Power: Foundations of Pentecostal Experience. Grand Rapids, MI: Zondervan, 2000.

Menzies, William W. Anointed to Serve. Springfield, MO: Gospel Publishing House, 1971.

Myland, D. Wesley. The Latter Rain Covenant and Pentecostal Power. Chicago, I L: The Evangel Publishing House, 1910. 
Nelson, P.C. Bible Doctrines (Springfield, MO: Gospel Publishing House, 1948)

Parham, Charles F. Voices in the Wilderness. Baxter Springs, Kansas: Apostolic Faith Bible College, n.d.

Pearlman, Myer. Knowing the Doctrines of the Bible. Springfield, MO: Gospel Publishing House, 1937

Reiter, Richard "A History of the Development of the Rapture Positions," in The Rapture: Pre, -Mid-, or Post- Tribulational? Grand Rapids, MI: Zondervan, 1984.

Ryrie, Charles C. Dispensationalism Today. Chicago, IL: Moody Bible Institute, 1965.

Seymour, William J. "Behold The Bridegroom Come" Apostolic Faith (January 1907):2

Sheppard, Gerald T. "Pentecostals and the Hermeneutics of Dispensationalism:

The Anatomy of an Uneasy Relationship," Pneuma (Fall 1994): 5-33

Synan, H. Vinson. The Holiness-Pentecostal Tradition: Charismatic Movemen in the Twentieth Century. Grand Rapids, MI: Wm. B. Eerdmans, 1997.

Voss, Howard F. An Introduction to Church History. Chicago, IL: Moody Press, 1984.

Weber, Timothy P. "Premillennialism and the Branches of Evangelicalism," in The Variety of American Evangelicalism. edited by Timothy P. Weber. Downers Grove, IL: IVP, 1991.

Williams, Ernest S. Systematic Theology. Springfield, MO: Gospel Publishing House, 1953.

Wilson, Lewis. "The Kerr-Pierce Role in A/G Education," Heritage (Spring 1990)

About the author:

Gani Wiyono, MTh., ThM. is a lecturer and academic dean of Satyabhakti Advanced School of Theology, Malang - INDONESIA. Email: gwiyono@gmail.com 